\title{
Neanderthals
}

\section{Katerina Harvati}

Published online: 23 July 2010

(C) Springer Science+Business Media, LLC 2010

\begin{abstract}
Neanderthals are a group of fossil humans that inhabited Western Eurasia from approximately 300 to 30,000 years ago (ka). They vanished from the fossil record a few millennia after the first modern humans appeared in Europe (ca. $40 \mathrm{ka} \mathrm{BP}$ ). They are characterized by a unique combination of distinctive anatomical features, and are found with stone tools of the Mousterian stone tool industry. Current consensus views them as a distinct Eurasian human lineage isolated from the rest of the Old World and sharing a common ancestor with modern humans sometime in the early Middle Pleistocene. The extreme cold of the European Ice Ages is considered at least partly responsible for the evolution of some of the distinctive Neanderthal anatomy, although other factors (functional demands, effects of chance in small populations) were probably also important. The causes for the Neanderthal extinction are not well understood. Worsening climate and competition with modern humans are implicated. Neanderthals were our sister species, much more closely related to us than the chimpanzees, our closest living relatives are today.
\end{abstract}

Keywords Eurasia $\cdot$ Ice age $\cdot$ Hominins .

Modern human origins

K. Harvati $(\bowtie)$

Department of Early Prehistory and Quaternary Ecology,

Eberhard Karls Universität Tübingen,

Rümelinstr. 23,

72070 Tübingen, Germany

e-mail: katerina.harvati@ifu.uni-tuebingen.de

K. Harvati

Senckenberg Center for Human Evolution and Paleoecology,

Eberhard Karls Universität Tübingen,

Rümelinstr. 23,

72070 Tübingen, Germany

\section{The Discovery of Neanderthals}

Neanderthal remains were already discovered in the early nineteenth century (Engis child in 1830, Forbes Quarry adult in 1848), but their significance was not recognized until the discovery of the skeleton from the Neander valley in 1856, roughly coinciding with the publication of Darwin's The Origin of Species in 1859. This locality lends its name to the group, and this discovery marks the beginning of the continuing debate surrounding the relationship of Neanderthals with modern humans.

The antiquity of the Neanderthal skeleton and its status as an extinct kind of human were not immediately accepted. Instead, its peculiar anatomy was attributed to various pathologies, including rickets. Its antiquity was only firmly established with the eventual discovery of additional similar skeletons that, unlike the Neanderthal skeleton, were found together with stone tools and with the bones of extinct animals. Once their status as fossil predecessors of modern humans was accepted, their relationship with modern humans, and particularly modern Europeans, began to be intensely debated. The predominant view in the 1910s and 1920s was represented by scientists like Marcellin Boule and Sir Arthur Keith, who were among the most influential scholars of their day. They placed Neanderthals in their own species, Homo neanderthalensis, and rejected any ancestral role for them in the evolution of modern people, pointing out their "primitiveness" and presumed inferiority (e.g., Boule 1911-1913).

This perception of Neanderthals changed starting in the 1930s. Mayr, Simpson, and Dobzhansky, among the fathers of the Modern Synthesis in Biology, placed Neanderthals and other Pleistocene fossil humans within our own species, Homo sapiens. According to this view, Neanderthals were thought to have evolved into modern people 
through slow, gradual evolution (Trinkaus and Shipman 1993; Tattersall 2000). This view has been reconsidered in more recent years, with new evidence coming from modern human and fossil genetic studies, the development of better dating techniques, and new approaches to the analysis of fossil anatomy. Currently, the majority of scientists view Neanderthals as a distinct, Western Eurasian evolutionary lineage, which probably did not contribute significantly to the evolution of modern people.

\section{Temporal and Geographic Range}

The earliest human remains known in Europe are dated to approximately 1.2 million years before present and were recovered in the Spanish site Sima del Elefante (Carbonell et al. 2008). These early European populations, sometimes referred to as Homo antecessor, are considered by some to have been ancestral to the later, European, Homo heidelbergensis and to Neanderthals (Bermudez de Castro et al. 1997), but may also represent unsuccessful early episodes of colonization that ended in local extinctions.

The appearance of Neanderthals in the fossil record is gradual. Neanderthal-like features appear for the first time in the European human fossils (also known as H. heidelbergensis) dating to as early as 600 thousand years before present (Bischoff et al. 2003). The frequency of Neanderthal features increases through time, with specimens dating from approximately 200 to 100 thousand years before present showing clear Neanderthal anatomy. The full suite of Neanderthal features appears with the "classic" Neanderthals in the Late Pleistocene, dated from approximately 70 to 30 thousand years before present. This gradual appearance of Neanderthallike features through time indicates a continuous evolutionary lineage in Europe from $H$. heidelbergensis to Neanderthals (although there is intense debate about the nature of the transition to Neanderthals from earlier humans, and about how many and which species are represented in the fossil record prior to the appearance of Neanderthals) (e.g., Rosas et al. 2006; Tattersall and Schwartz 2006). This process of Neanderthal evolution has been described as the "Accretion Model" (e.g., Dean et al. 1998; Hublin 2009).

Neanderthals disappeared from the fossil record approximately 30,000 years before present, only a few millennia after the first appearance of modern humans in Europe around 40,000 years ago. A very recent date of 24,000 years ago as the date of last appearance of Neanderthals in Iberia (Finlayson et al. 2006) is not secure due to stratigraphic inconsistencies (Delson and Harvati 2006), and its validity remains to be confirmed.

Within Europe, Neanderthals range from Iberia to Russia and from the Mediterranean to Northern Europe (Fig. 1). It has been hypothesized that the southern peninsulas of
Europe may have acted as refugia for Neanderthal populations during glacial intervals, allowing for their survival during extreme climatic conditions when more northern regions of the continent would have been uninhabitable (e.g., Finlayson et al. 2006; Harvati et al. 2003, 2009). Outside the strict boundaries of Europe, a Neanderthal presence has been documented in the Near East and in Western Asia as far east as Uzbekistan and even Siberia (Krause et al. 2007a).

\section{Anatomy and Paleobiology}

Neanderthals are characterized by a multitude of distinctive cranial, mandibular, dental, and postcranial anatomical features (Fig. 2), many of which are unique to them. Neanderthals also show several "primitive" features, i.e., features shared with the common ancestor of both Neanderthals and modern humans (see Harvati 2007).

The Neanderthal face is characterized by a heavy, continuous, and double-arched bony brow ridge. The eye sockets are large and rounded. The nasal opening is very large and broad, with a voluminous nasal cavity. There is a pronounced projection of the midface, and the cheekbones are obliquely oriented and "inflated." Internally, the maxillary sinuses are large, while the frontal sinus is expanded laterally to fill most of the bony brow ridge. The Neanderthal lower jaw is receding and lacks a protruding chin; furthermore, there is a distinct space between the lower wisdom teeth and the vertical branch of the lower jaw (Heim 1976; Stringer et al. 1984; Rak 1986, 1998; Trinkaus 1987; Schwartz and Tattersall 1996; Arsuaga et al. 1997; Franciscus 2003; Nicholson and Harvati 2006). The dimensions of the Neanderthal back teeth completely overlap with those of the teeth of modern humans. However, Neanderthal front teeth, and particularly the incisors, are larger, and several dental anatomical features appear much more frequently in Neanderthals compared to modern humans (Bailey 2002, 2004). The Neanderthal dentition is also worn down in a distinctive pattern, with the front teeth usually worn down much more than the back teeth of the same individual (Keith 1913; Trinkaus 1983).

The Neanderthal large nasal opening and associated structures have long been proposed to relate to cold-climate adaptation, and are thought by some scholars to function in warming and humidifying inspired air, as well as in dissipating heat (e.g., Coon 1962; Dean 1988; Hubbe et al. 2009). Another interpretation sees the Neanderthal facial features as biomechanical consequences of intense paramasticatory behavior (i.e., using their teeth as tools), as evidenced by the unusual anterior tooth wear pattern exhibited by many Neanderthals (e.g., Heim 1976; Rak 1986; Trinkaus 1987). A third interpretation considers Neanderthal facial morphology as primarily the result of 


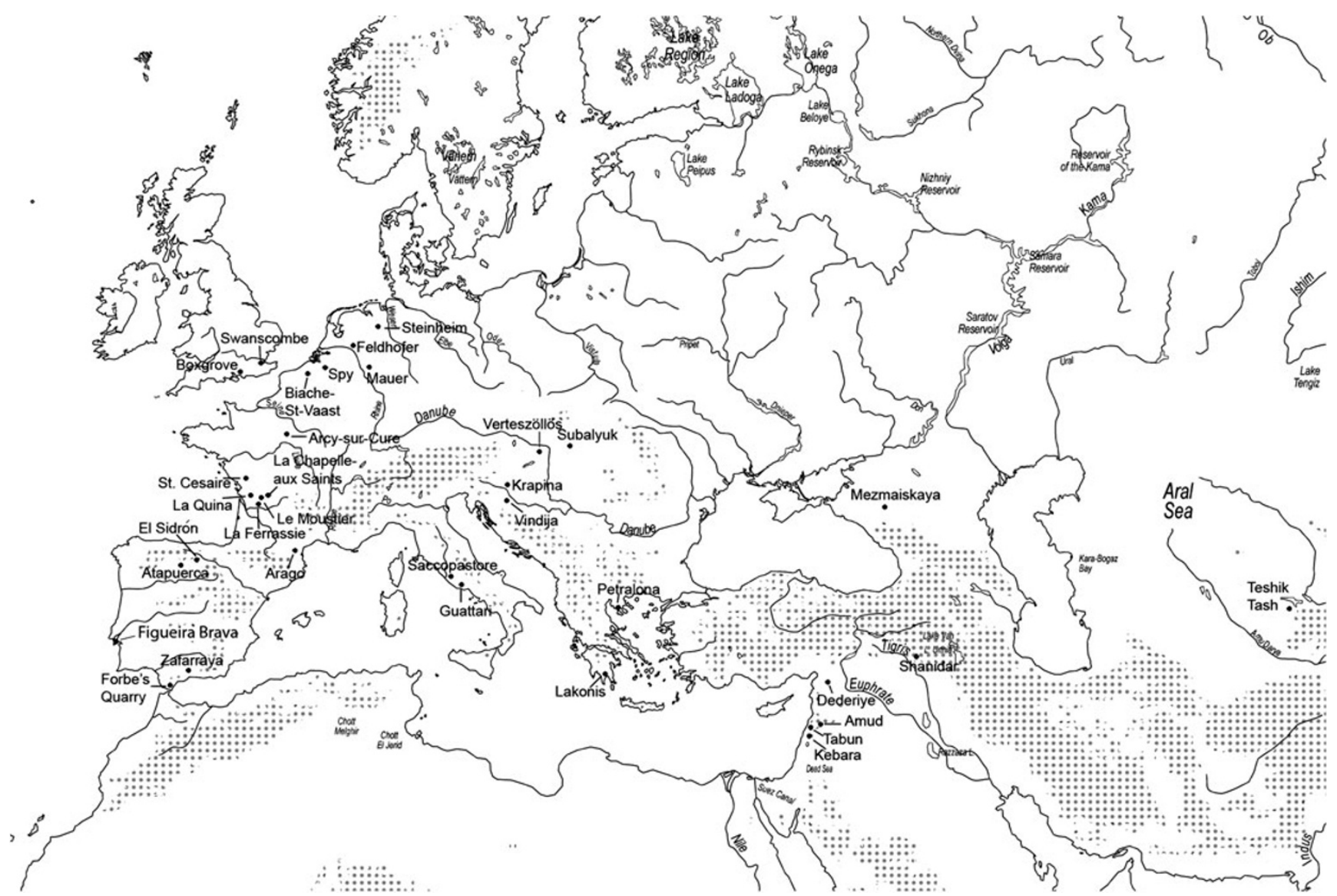

Fig. 1 Map of the geographic distribution of Neanderthals, showing important Neanderthal and pre-Neanderthal sites. Adapted from Harvati 2007

chance-driven processes (genetic drift; e.g., Hublin 1998; Weaver et al. 2007).

The Neanderthal skull looks flat and elongated when viewed from the side, and rounded when viewed from the back. The back of the skull projects backward, in what is termed an "occipital bun" or "chignon" (Boule 1911-1913; Hublin 1988a, b, 1998; Stringer et al. 1984; Condemi 1988; Lieberman 1995; Schwartz and Tattersall 1996; Dean et al. 1998; Gunz and Harvati 2007). The temporal (temple) bone shows several marked differences from that of modern humans (Harvati 2003b). Recent examination of the internal morphology of the inner ear using computer tomography scans has revealed a distinctive shape for the Neanderthal bony labyrinth (Spoor et al. 2003).

Neanderthal average brain size is larger than that of modern humans, measuring approximately 1520 cubic centimeters (from 1,200 to 1,700 cubic centimeters; Holloway 1985). Large brains might also be related to cold-climate adaptation in these extinct humans (Churchill 1998). Even though absolute brain size was larger on average in Neanderthals relative to modern humans, their relative brain size may have been smaller due to their greater body mass (e.g., Ruff et al. 1997). The brain enlargement characteristic of both Neander- thals and modern humans appears to have followed distinct evolutionary trajectories in the two lineages, with Neanderthals retaining an archaic brain shape despite larger size, and modern humans exhibiting distinct shape, as well as increasing size (Bruner et al. 2004).

The Neanderthal skeleton is overall robust, with markedly curved shafts of the femur (thigh) and radius (lower arm), thick bone, and strong muscle and ligament markings. Estimated stature averages about 169 centimeters for males and about 160 centimeters for females, shorter than that of early modern humans. Body mass is estimated at about 78 kilograms (about 160 pounds) for males and about 66 kilograms (about 145 pounds) for females. Neanderthal skeletons are also characterized by ribcages which are broad and deep at the bottom and narrow at the top (Franciscus and Churchill 2002; Sawyer and Maley 2005); relatively short distal limbs (i.e., lower arms and legs) and large articular ends of the tibia (shin) and femur (thigh) (Boule 1911-1913; Trinkaus 1983; Ruff 1991; Ruff et al. 1997; Weaver 2003). Several of these traits have been linked to high activity levels and/or cold-climate adaptation. Neanderthal body proportions are commonly viewed as adapted to cold conditions. The short stature and short 


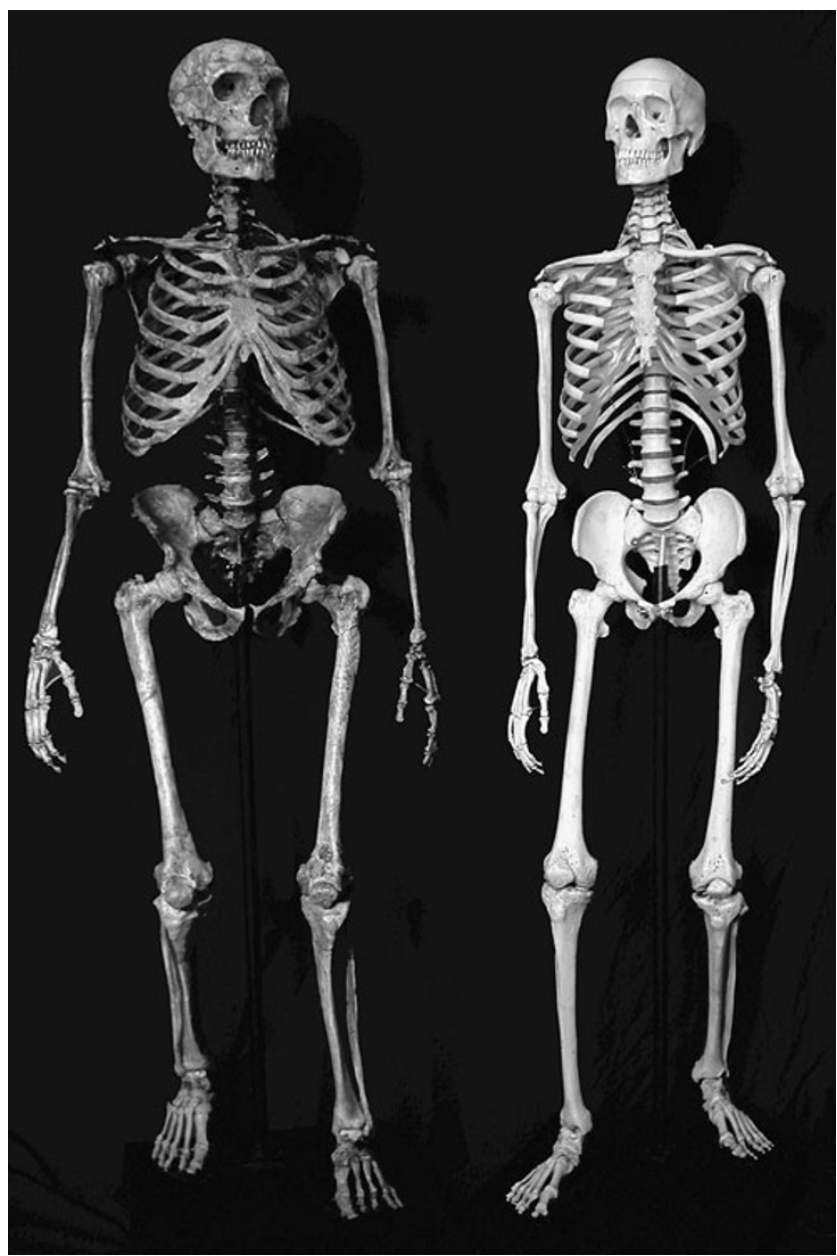

Fig. 2 Complete Neanderthal skeleton (left) reconstructed using elements from five partial skeletons (principally La Ferrassie 1 and Kebara 2) compared with a modern human skeleton (right). Courtesy of and copyright Ian Tattersall, American Museum of Natural History

distal limb proportions are thought to follow Bergmann's and Allen's rules for cold environments, as seen also in wide ranging mammal species and some modern human populations (e.g., Holliday 1997). Overall robusticity, wide trunks, and features of the Neanderthal femur and pelvis have also been interpreted as relating to cold climate (e.g., Pearson 2000; Weaver 2003). However, a recent estimate of the ability of the Neanderthal body shape to withstand cold temperatures showed only a small advantage over early modern humans with a less "cold-adapted" body form (Aiello and Wheeler 2003). This indicates that Neanderthals could not have inhabited high-latitude habitats without some form of shelter and clothing.

From the small number of studies that have been carried out so far, it appears that Neanderthal children grew faster than modern human children (Dean et al. 2001; Ramírez Rozzi and Bermúdez de Castro 2004; Smith et al. 2007). Neanderthals also seem to have had distinct demographics: The percentage of adolescents and prime age adults recovered from Neanderthal sites is unusually high relative to that of older adults and infants (commonly more frequent in modern human cemetery populations). This pattern suggests a high mortality among young and prime age Neanderthals, with corresponding low adult life expectancy. The reasons for this high mortality are probably related to the high levels of stress and trauma also observed on Neanderthal skeletons. Signs of injury can be found on almost every well-preserved adult Neanderthal skeleton (Trinkaus 1995; Berger and Trinkaus 1995) and are concentrated in the head and neck, producing an uncommon pattern of injury that may have resulted from hunting strategies requiring proximity to large prey animals (Berger and Trinkaus 1995). Some of them have also been argued to result from interpersonal aggression (e.g., Churchill et al. 2009). The majority of injuries are healed or partially healed, therefore suggesting that Neanderthals showed some level of compassion: Many of the injured individuals would not have survived the period of convalescence without being cared for by others (Trinkaus 1983). In addition to injury, Neanderthal remains show elevated developmental stress, suggesting an elevated level of hardship during childhood and throughout life (e.g., Ogilvie et al. 1989; but see Guattelli-Steinberg et al. 2004).

\section{Neanderthal Genetics}

Neanderthals were the first extinct species to yield genetic information. The first glimpse of their mitochondrial DNA (or mtDNA: genetic material found in the mitochondria, a kind of cellular organelle, outside the cell nucleus; it is inherited exclusively through the maternal line) came with the publication of the seminal article by Krings and colleagues in 1997 (Krings et al. 1997). These researchers were able to recover mtDNA from the Neanderthal (Feldhofer 1) specimen, and to compare it to the homologous (equivalent) mtDNA from several different modern human populations. The Neanderthal pattern of mtDNA was outside the range of modern human variation and was equally dissimilar to modern human sequences from different geographic regions. This study pointed to a last common ancestor for the mitochondrial genome of Neanderthals and modern humans between approximately 317,000 and 741,000 years ago.

More recently the same mitochondrial DNA has been sequenced partially or in whole for seventeen Neanderthal specimens from sites across Europe and Western Asia (Krings et al. 1997, 2000; Ovchinnikov et al. 2000; Schmitz et al. 2002; Serre et al. 2004; Beauval et al. 2005; Lalueza-Fox et al. 2005, 2006; Caramelli et al. 2006; Orlando et al. 2006; Krause et al. 2007a; Green et al. 2008). All have produced similar sequences, which group together and are distinct 
from those of modern humans. In contrast, all of the earliest European modern human specimens so far tested have yielded only modern human-like, and no Neanderthal-like, mtDNA sequences (Caramelli et al. 2003; Serre et al. 2004). These findings support the earlier conclusion of very small or negligible contribution of Neanderthals to modern human ancestry. Estimates based on these studies place the most recent mtDNA ancestor of all Neanderthals to approximately 250,000 years ago. (Lalueza-Fox et al. 2005; Caramelli et al. 2006). The divergence between modern human and Neanderthal mtDNA lineages, on the other hand, is estimated at 660,000 or more years ago to 140,000 years ago (Green et al. 2008).

In the last few years, scientists have begun deciphering the nuclear DNA of Neanderthals with the goal of assembling the Neanderthal genome. This work has not been completed yet, but has produced some interesting results. Among these is the discovery that Neanderthals share with modern humans the FOX P2 gene variant, one of the genes affecting language abilities, which was previously thought to be unique to modern humans (Enard et al. 2002; Krause et al. 2007b). A draft sequence of the Neanderthal genome published recently suggested a limited contribution (one to four percent) of Neanderthals to modern people from Eurasia (Green et al. 2010; see below). This study also estimated the average date of divergence of the Neanderthal and modern human autosomal (i.e., found in the nucleus) DNA at 825,000 years before present. Because gene divergence before populations actually separate, this estimate also puts the population divergence of Neanderthal and modern human ancestors between 270,000 and 440,000 years ago (Green et al. 2010).

\section{Technology, Diet, and Behavior}

Neanderthals are most commonly, though not exclusively, associated with the Mousterian stone tool technology, named after the site of Le Moustier in the Dordogne, France. Mousterian industries typically feature Levallois and discoidal flaking techniques for the production of stone flakes that could be converted to a wide range of shapes and tools (Debénath and Dibble 1994; Mellars 1996; Shea and Brooks 2000). Mousterian industries appear in Europe as early as around 200,000 to 150,000 years ago and possibly earlier in the Near East, but most sites are dated to the interval from about 130,000 to 30,000 years ago. The stone used for the production of stone tools in most Mousterian sites tends to derive from within a five- to six-kilometer range from the site, and only a very small component originates from more distant sources (Mellars 1996). This suggests relatively small territorial ranges. Some points appear to have been hafted, and were probably used as spear points (Mellars 1996; Shea and Brooks 2000). Wooden tools were probably also made, as is evidenced by several well-preserved wooden spears discovered in Schöningen and dated to approximately 400,000 thousand years ago (Thieme 2000), and by parts of similar implements from Clacton-on-Sea (possibly around 350,000 years ago) and Lehringen (around 130,000 to 110,000 years ago; Mellars 1996). Neanderthal sites show relatively little structure compared with later Upper Paleolithic (modern human) sites. The living areas are small and show no clear focus of activity, while artificial structures such as walls are rare. Hearths are well defined and were probably central in tool production and food processing (Mellars 1996). Controlled use of fire appears widespread in Europe approximately 400,000 years before present onward, and possibly earlier (e.g., Gowlett 2005).

Until recent years, the Mousterian was commonly thought to represent a static culture. However, redating of Mousterian sites has shown changes with time in regional industries as well as technological responses to climatic change (Kuhn 1995; Shea and Brooks 2000). Some "transitional" Middle-Upper Paleolithic stone tool industries, like the Châtelperronian industry in France, the Uluzzian in Italy, and the Szeletian in East-Central Europe, combine strong similarities with the Mousterian with modern technological elements. These transitional industries date from the period of overlap of Neanderthals and early modern humans in Europe (approximately 40,000 to 30,000 years ago) and were originally thought to have been made by early modern humans. Since the discovery of Neanderthal remains associated with such industries, however, they are now thought to have been produced by late Neanderthal populations. This discovery opened up the possibility of Neanderthal acculturation by, or trade with, early modern humans and prompted debate over the cognitive capacities of Neanderthals (see, e.g., d'Errico et al. 1998; Zilhão and D'Errico 1999; Mellars 1999, 2005).

Neanderthal sites abound in faunal remains of various animals, indicating a high reliance on meat in their diet. Animals such as bison, wild cattle, horse, reindeer, red and fallow deer, ibex, wild boar, and gazelle are commonly found (Shea and Brooks 2000). Neanderthal sites from the Mediterranean region also preserve evidence for consumption of other food sources, such as shellfish, birds, and marine mammals (Stiner 1994; Barton 2000; Currant 2000; Hockett and Haws 2005; Stringer et al. 2008). Plant remains in Neanderthal sites are relatively rare, but probably this is a bias due to the poor preservation of such fragile remains in the fossil record.

Neanderthal diets have also been assessed through the study of the chemical composition of the Neanderthal skeletons themselves. Analysis of the ratios of stable isotopes of carbon and nitrogen in these bones has been undertaken for a number of Neanderthal specimens from a 
wide temporal range (about 130,000 to about 30,000 years ago). So far, such analyses have invariably indicated a very strong reliance on herbivore meat, with Neanderthals being similar to top predators in the isotopic composition of their bones (Fizet et al. 1995; Bocherens et al. 1999; Richards et al. 2000; Bocherens et al. 2005). Some of these studies also suggested a much greater consumption of very large animals, such as wholly rhinoceros or wholly mammoth, than was previously thought (see Bocherens et al. 2005). The isotopic analyses agree with zooarchaeological studies in finding a very small component of marine foods in Neanderthal diets, in sharp contrast with Upper Paleolithic modern humans (see Richards et al. 2001, 2005). However, no isotopic analysis has yet been conducted for Neanderthal specimens from the Mediterranean coast, whose diets may have been more varied.

The Neanderthal ability for symbolic thought and language remains an open question. "Symbolic" objects that might suggest such capabilities, such as objects of art or personal ornamentation, are extremely rare in Neanderthal sites, compared not only with later Upper Paleolithic sites (Mellars 1996) but also with some African sites from the same time period (e.g., McBrearty and Brooks 2000; Henshilwood et al. 2001). The lack of such objects has been argued to indicate a lack of human cognitive abilities and language. However, it should be kept in mind that the archeological record is an imperfect record of behavior, perhaps in this case resulting in a biased documentation (or lack thereof) of Neanderthal symbolic activities. Evidence in support for Neanderthal ability for some symbolic thought is the occurrence of ochre and manganese "crayons" in Neanderthal sites, and the burial of at least some individuals. Nevertheless, evidence for grave goods and other burial practices is scant (Mellars 1996; Shea and Brooks 2000).

\section{Sister Species}

Ever since their assignment to the distinct species $H$. neanderthalensis (King 1864), the classification of Neanderthals and their role in human evolution have been the subject of intense discussion. It is now commonly recognized that Neanderthals and earlier Middle Pleistocene European fossils form a separate evolutionary lineage, at least partly geographically isolated in Western Eurasia. Certainly, the number and magnitude of anatomical differences between Neanderthals and modern humans is such that it warrants their recognition as a separate species, and their exclusion from Homo sapiens (e.g., Stringer 1974; Tattersall 1992; Stringer and Andrews 1988; Hublin 1998; Harvati 2003b; Harvati et al. 2004). There is no doubt that Neanderthals were our close relatives, much more closely related to us than our closest living relatives, the chimpanzees, and can be regarded as our sister species. What is still unclear, however, is the nature of the interaction between Neanderthals and modern humans arriving in Europe approximately 40,000 years ago. Since Neanderthals and modern humans overlapped in Europe for up to 10,000 years (Stringer et al. 2003), it is widely thought that the two species would have met at least on some occasions.

There is no agreement as to whether Neanderthals and early modern humans were able to reproduce successfully, as closely related mammal species often do. Some paleoanthropologists see evidence for Neanderthal-like features in early modern European specimens and for trends of "modernization" in some late Neanderthal samples (e.g., Smith 1982, 1991; Frayer et al. 1993; Ahern et al. 2002; Trinkaus et al. 2003). However, others find no evidence of intermediate morphology (e.g., Bräuer and Broeg 1998; Bräuer et al. 2006; Bailey 2002; Harvati 2003a, 2009; Harvati et al. 2004, 2007). A recent claim for a Neanderthal-modern human hybrid from Portugal dated to approximately 24,000 years ago (Duarte et al. 1999) is difficult to substantiate because this specimen is a child and because its geological age of approximately 24,000 years before present places it several thousand years after the disappearance of the last Neanderthals (Tattersall and Schwartz 1999). Another proposed hybrid, an adult early Upper Paleolithic individual from the Cioclovina site, Romania (Soficaru et al. 2007), has been disputed on the basis of several criteria for recognizing hybrids from skeletal remains; this specimen appears completely modern in its anatomy (Harvati et al. 2007).

From a molecular perspective, the mtDNA of Neanderthals and Upper Paleolithic Europeans shows no evidence for admixture between the two groups (Serre et al. 2004; Green et al. 2008). Demographic models of the Neanderthal-modern human interaction based on the ancient DNA available data suggested that, although possible, a contribution of Neanderthals to the modern human gene pool would have been very small (less than one to two percent; Currat and Excoffier 2004; Weaver and Roseman 2005). The recent publication of a draft of the Neanderthal autosomal genome (i.e., the complete, rather than just the mitochondrial, genome of Neanderthals) compared the Neanderthal genome with the genomes of five modern humans (one of each from France, China, Papua New Guinea, South Africa [San], and West Africa) (Green et al. 2010). This comparison found that the Neanderthal genome was somewhat more similar to that of all three Eurasians than it was to the two African individuals, suggesting that some interbreeding occurred. Nonetheless, it seems that it would have been only a rare occurrence and contributed one to four percent of the genetic material of modern Eurasians. Furthermore, since these similarities are shared 
with all Eurasians rather than just Europeans, the authors suggested that this must have occurred prior to the expansion of modern people throughout the Old World and possibly in the Near East (Green et al. 2010). Therefore, even though interbreeding seems to have been possible, it seems to have been a rare event and to have occurred at a very low level.

\section{The Neanderthal Extinction}

For some researchers, the last appearance of Neanderthals simply signifies their evolution into modern Europeans or their assimilation into the modern human gene pool. Most, however, view it as a true extinction, even if limited genetic exchanges with modern humans took place. Several scenarios for the Neanderthal extinction have been proposed, and often they invoke some direct or indirect competition with early modern humans. Proposed modern human competitive advantages include demographic and subsistence factors, such as larger group sizes, slightly higher birth rates, lower mortality rates, shorter interbirth spacing, greater dietary diversity, more complex social networks, and better clothing and shelter in modern humans (Zubrow 1989; Skinner 1997; Flores 1998; Gat 1999; Richards et al. 2001; Stringer et al. 2003; Hockett and Haws 2005). Some researchers propose that their extinction can be viewed as one of the many Late Pleistocene megafauna extinctions caused by the loss of an environment with no modern analogue (Stewart et al. 2003; Stewart 2005).

Some paleoanthropologists consider worsening climatic and environmental conditions to have been major driving forces in the Neanderthal extinction (e.g., Finlayson 2004). Recently available detailed paleoclimatic records have shown that the time period of the Neanderthal disappearance was dominated by very unstable climatic conditions (van Andel and Davies 2003). However, none of the proposed dates for the Neanderthal extinction coincides or immediately precedes a major cooling episode, rejecting the hypothesis that catastrophic climate deterioration was the cause for the Neanderthal disappearance (Tzedakis et al. 2007). The fact that Neanderthals had successfully survived previous cold phases also makes it difficult to accept climate change as the sole reason for their demise. An alternative interpretation sees the advent of modern humans, perhaps with better cultural buffering and more effective social networks, as providing the coup de grâce to the highly stressed Neanderthal populations through competition for severely limited resources during the critical time interval of their co-existence in Europe (Stringer et al. 2003; Lahr and Foley 2003; Harvati 2007). In this view, it is the interaction between the effects of fluctuating climate and environment and of competition with modern humans that led to the eventual Neanderthal demise.

\section{References}

Ahern JCM, Lee SH, Hawks JD. The late Neandertal supraorbital fossils from Vindija cave, Croatian: a biased sample? J Hum Evol. 2002;43:419-32.

Aiello LC, Wheeler P. Neanderthal thermoregulation and the glacial climate. In: van Andel T, Davies W, editors. Neanderthals and modern humans in the European landscape during the last glaciation. Cambridge: McDonald Institute for Archaeological Research; 2003. p. 147-66.

Arsuaga JL, Martinez I, Gracia A, Lorenzo C. The Sima de los Huesos crania (Sierra de Atapuerca, Spain). A comparative study. J Hum Evol. 1997;33:219-81.

Bailey SE. A closer look at Neanderthal postcanine dental morphology: the mandibular dentition. Anat Rec (New Anat). 2002;269:148-56.

Bailey SE. A morphometric analysis of maxillary molar crowns of Middle-Late Pleistocene hominins. J Hum Evol. 2004;47:183-98.

Barton RNE. Mousterian hearths and shellfish: Late Neanderthal activities on Gibraltar. In: Stringer CB, Barton RNE, Finlayson JC, editors. Neanderthals on the Edge: Papers from a conference marking the $150^{\text {th }}$ anniversary of the Forbes' Quarry discovery, Gibraltar. 2000. pp. 211-220.

Beauval C, Maureille B, Lacrampe-Cuyaubere F, Serre D, Peressinotto D, Bordes JG, et al. A late Neandertal femur from Les Rochersde-Villeneuve, France. Proc Natl Acad Sci USA. 2005;102:708590.

Berger TD, Trinkaus E. Patterns of trauma among the Neandertals. J Archaeol Sci. 1995;22:841-52.

Bermudez de Castro JM, Arsuaga JL, Carbonell E, Rosas A, Martinez I, Mosquera M. A hominid from the Lower Pleistocene of Atapuerca, Spain: possible ancestor to Neandertals and modern humans. Science. 1997;276:1392-5.

Bischoff JL, Shamp DD, Aramburu A, Arsuaga JL, Carbonell E, Bermudez de Castro JM. The Sima de los Huesos hominids date to beyond U/Th equilibrium ( $>350 \mathrm{kyr}$ ) and perhaps to 400 500 kyr: new radiometric dates. J Archaeol Sci. 2003;30:275-80.

Bocherens H, Billiou D, Mariotti A, Patou-Mathis M, Otte M, Bonjean D, et al. Palaeoenvironmental and palaeodietary implications of isotopic biogeochemistry of late interglacial neanderthal and mammal bones in Scladina cave (Belgium). J Archaeol Sci. 1999;26:599-607.

Bocherens H, Drucker DG, Billiou D, Patou-Mathis M, Vandermeersch B. Isotopic evidence for diet and subsistence pattern of the SaintCésaire I Neanderthal: review and use of a multi-source mixing model. J Hum Evol. 2005;49:71-87.

Boule M (1911-1913) L'homme fossile de la Chapelle-aux-Saints. Annls Paléont 6:11-172; 7:21-56; 8:1-70.

Bräuer G, Broeg H. On the degree of Neandertal-modern continuity in the earliest Upper Paleolithic crania from the Czech Republic: evidence from non-metrical features. In: Omoto K, Tobias PV, editors. Recent advances in human biology, The origins and past of modern humans: towards reconciliation, vol. 3. Singapore: World Scientific; 1998. p. 106-25.

Bräuer G, Broeg H, Stringer C. Earliest Upper Paleolithic crania from Mladeč, Czech Republic, and the question of Neanderthalmodern continuity: metrical evidence from the fronto-facial region. In: Harvati K, Harrison T, editors. Neanderthals revisited: new approaches and perspectives. Berlin: Springer; 2006. p. 269 80.

Bruner E, Manzi G, Arsuaga JL. Encephalization and allometric trajectories in the genus Homo: evidence from the Neandertal and modern lineages. Proc Natl Acad Sci USA. 2004;100:15335-40.

Caramelli D, Lalueza-Fox C, Vernesi C, Lari M, Casoli A, Mallegni F, et al. Evidence for a genetic discontinuity between Neandertals 
and 24, 000-year-old anatomically modern Europeans. Proc Natl Acad Sci USA. 2003;100:6593-7.

Caramelli D, Lalueza-Fox C, Condemi S, Longo L, Milani L, Manfredini A, et al. A highly divergent mtDNA sequence in a Neandertal individual from Italy. Curr Biol. 2006;16:R630-2.

Carbonell E, Bermu'dez de Castro JM, Pare's JM, Pe'rez-Gonza'lez A, Cuenca-Besco's G, Olle' A, et al. The first hominin of Europe. Nature. 2008;452:465-9.

Churchill SE. Cold adaptation, heterochrony and Neandertals. Evol Anthropol. 1998;7:46-61.

Churchill SE, Franciscus RG, McKean-Peraza HA, Daniel JA, Warren BR. Shanidar 3 Neandertal rib puncture wound and paleolithic weaponry. J Hum Evol. 2009;57:163-78.

Condemi S (1988) Caracteres plesiomorphes et apomorphes de l'os temporal des neanderthaliens europeens würmiens. In: Trinkaus E (ed) L'Homme de Neandertal, l'anatomie, 3, ERAUL 30, Liège pp. 49-52.

Coon CS. The origin of races. New York: Knopf; 1962.

Currant AP. A review of the Quaternary mammals of Gibraltar. In: Stringer CB, Barton RNE, Finlayson JC, editors. Neanderthals on the Edge: Papers from a conference marking the $150^{\text {th }}$ anniversary of the Forbes' Quarry discovery, Gibraltar. 2000. pp. 201-205.

Currat M, Excoffier L. Modern humans did not admix with Neanderthals during their range expansion into Europe. PLoS Biol. 2004;2:e421.

Dean MC. Another look at the nose and the functional significance of the face and nasal mucous membrane for cooling the brain in fossil hominids. J Hum Evol. 1988;17:715-8.

Dean D, Hublin JJ, Holloway R, Ziegler R. On the phylogenetic position of the pre-Neanderthal specimen from Reilingen, Germany. J Hum Evol. 1998;34:485-508.

Dean C, Leakey MG, Reid D, Schrenk F, Schwartz GT, Stringer C, et al. Growth processes in teeth distinguish modern humans from Homo erectus and earlier hominins. Nature. 2001;414:628-31.

Debénath A, Dibble HL. Handbook of paleolithic typology, vol. 1: lower and middle paleolithic of Europe. Philadelphia: Cypher; 1994.

Delson E, Harvati K. Return of the last Neanderthal. Nature. 2006;443:762-3.

d'Errico F, Zilhão J, Julien M, Baffier D, Pelegrin J. Neanderthal acculturation in Western Europe? A critical review of the evidence and its interpretation. Curr Anthropol. 1998;39:S1-S44.

Duarte C, Mauricio J, Pettitt PB, Souto P, Trinkaus E, van der Plicht $\mathrm{H}$, et al. The early Upper Paleolithic human skeleton from the Abrigo do Lagar Velho (Portugal) and modern human emergence in Iberia. Proc Natl Acad Sci USA. 1999;96:7604-9.

Enard W, Przeworski M, Fisher SE, Lai CSL, Wiebe V, Kitano T, et al. Molecular evolution of FOXP2, a gene involved in speech and language. Nature. 2002;418:869-72.

Finlayson C. Neanderthals and modern humans. Cambridge: Cambridge University Press; 2004.

Finlayson C, Pacheco FG, Rodríguez-Vidal J, Fa DA, Gutierrez López $\mathrm{JM}$, Pérez AS, et al. Late survival of Neanderthals at the southernmost extreme of Europe. Nature. 2006;443:850-3.

Fizet M, Mariotti A, Bocherens H, Lange-Badre B, Vandermeersch B, Borel J, et al. Effect of diet, physiology and climate on carbon and nitrogen stable isotopes of collagen in a late pleistocene anthropic palaeoecosystem: Marillac, Charente, France. J Archaeol Sci. 1995;22:67-79.

Flores J. A mathematical model for the Neanderthal extinction. J Theor Biol. 1998;191:295-8.

Franciscus RG. Internal nasal floor configuration in Homo with special reference to the evolution of Neandertal facial form. $\mathrm{J}$ Hum Evol. 2003;44:701-29.

Franciscus RG, Churchill SE. The costal skeleton of Shanidar 3 and a reappraisal of Neandertal thoracic morphology. J Hum Evol. 2002;42:303-56.
Frayer DW, Wolpoff MH, Thorne AG, Smith FH, Pope GG. Theories of modern human origins: the paleontological test. Am Anthropol. 1993;95:14-50.

Gat A. Social organization, group conflict and the demise of Neanderthals. Mank Q. 1999;39:437-54.

Green RE, Malaspinas AS, Krause J, Briggs AW, Johnson PLF, Uhler C, et al. A complete Neandertal mitochondrial genome sequence determined by high-throughput sequencing. Cell. 2008;134:416-26.

Green RE, Krause J, Briggs AW, Maricic T, Stenzel U, Kircher M, et al. A draft sequence of the Neandertal genome. Science. 2010;328:710-22

Gowlett JAJ. The early settlement of northern Europe: fire history in the context of climate change and the social brain. Comptes Rendus Palevol. 2005;5:299-310.

Guattelli-Steinberg D, Spenser Larsen C, Hutchinson D. Prevalence and the duration of linear enamel hypoplasia: a comparative study of Neandertals and Inuit foragers. J Hum Evol. 2004;47:67-84.

Gunz P, Harvati K. The Neanderthal 'chignon': variation, integration and homology. J Hum Evol. 2007;52:262-74.

Harvati K. The Neanderthal taxonomic position: models of intra- and inter-specific craniofacial variation. J Hum Evol. 2003a;44:107-32.

Harvati K. Quantitative analysis of Neanderthal temporal bone morphology using 3-D geometric morphometrics. Am J Phys Anthropol. 2003b;120:323-38.

Harvati K. Neanderthals and their contemporaries. In: Henke W, Tattersall I, editors. Handbook of paleoanthropology, Phylogeny of Hominines, vol. 3. Berlin: Springer; 2007. p. 1717-48.

Harvati K. Into Eurasia: Geometric morphometric analysis of the Upper Cave (Zhoukoudian) specimens. J Hum Evol. 2009;57:751-62.

Harvati K, Panagopoulou E, Karkanas P. First Neanderthal remains from Greece: the evidence from Lakonis. J Hum Evol. $2003 ; 45: 465-73$.

Harvati K, Frost SR, McNulty KP. Neanderthal taxonomy reconsidered: implications of 3D primate models of intra- and interspecific differences. Proc Natl Acad Sci USA. 2004;101:1147-52.

Harvati K, Gunz P, Grigorescu D. Cioclovina (Romania): affinities of an early modern European. J Hum Evol. 2007;53:732-46.

Harvati K, Panagopoulou E, Runnels C. The Paleoanthropology of Greece. Evol Anthropol. 2009;18:131-43.

Heim JL. Les hommes fossiles de LA Ferrassie I: Legisement, les squelettes adultes (crâne et squelette du troc). Arch Inst Paléontol Hum. 1976;35:1-131.

Henshilwood CS, d'Errico F, Marean CW, Milo RG, Yates R. An early bone tool industry from the Middle Stone Age at Blombos Cave, South Africa: implications for the origins of modern human behaviour, symbolism and Language. J Hum Evol. 2001:41:631-78.

Hockett B, Haws JA. Nutritional ecology and the human demography of Neandertal extinction. Quat Int. 2005;137:21-34.

Holliday TW. Postcranial evidence of cold adaptation in European Neanderthals. Am J Phys Anthropol. 1997;104:245-58.

Holloway RL. The poor brain of Homo sapiens neanderthalensis: see what you please. In: Delson E, editor. Ancestors: the hard evidence. New York: Alan R. Liss; 1985. p. 319-24.

Hubbe M, Hanihara T, Harvati K. Climate signatures in the morphological differentiation of worldwide human populations. Anat Rec. 2009;292:1720-33. doi:1002/ar.20976.

Hublin JJ. Caractères derivés de la region occipitomasto-dienne chez les Néandertaliens. L'Anatomie, L'Homme de Néandertal. 1988a;3:67-73.

Hublin JJ. Les plus ancients répresentants de la lignée prenéanderthalienne. L'Anatomie, L'Homme de Néandertal. 1988b;3:81-94.

Hublin JJ. Climatic changes, paleogeography and the evolution of Neanderthals. In: Aoki K, Bar-Yosef O, editors. Neanderthals and 
Modern Humans in Western Asia. New York: Plenum; 1998. p. 295-310.

Hublin JJ. The origin of Neandertals. Proc Natl Acad Sci USA. 2009; 106:16022-7.

Keith A (1913) Problems relating to the earlier forms of prehistoric man. Proc R1 Soc Medic (Odontol) 6103-6119.

King W. The reputed fossil man of the Neanderthal. Q J Sci. 1864;1:88-97.

Krause J, Lalueza-Fox C, Orlando L, Enard W, Green RE, Burbano HA, et al. The derived FOXP2 variant of modern humans was shared with Neandertals. Curr Biol. 2007a;17:1908-12.

Krause J, Orlando L, Serre D, Viola B, Prufer K, Richards MP, et al. Neanderthals in central Asia and Siberia. Nature. 2007b;449:902-4.

Krings M, Stone A, Schmitz RW, Krainitzki H, Stoneking M, Päabo $\mathrm{S}$. Neandertal DNA sequences and the origin of modern humans. Cell. 1997;90:19-30.

Krings M, Capelli C, Tschentscher F, Geisert H, Meyer S, von Haessler A, et al. A view of Neandertal genetic diversity. Nat Genet. 2000;26:144-6.

Kuhn SL. Mousterian lithic technology: an ecological perspective. Princeton: Princeton University Press; 1995.

Lahr MM, Foley RA. Demography, dispersal and human evolution in the Last Glacial Period. In: van Andel T, Davies W, editors. Neanderthals and modern humans in the European landscape during the last glaciation. Cambridge: McDonald Institute for Archaeological Research; 2003. p. 241-56.

Lalueza-Fox C, Sampietro ML, Caramelli D, Puder Y, Lari M, Calafell F, et al. Neanderthal evolutionary genetics, mitochondrial DNA data from the Iberian Peninsula. Mol Biol Evol. 2005;22:1077-81.

Lalueza-Fox CM et al. DNA of an Iberian Neandertal suggests a population affinity with other European Neandertals. Curr Biol. 2006; 16:R629-30.

Lieberman DE. Testing hypotheses about recent human evolution from skulls: Integrating morphology, function, development and phylogeny. Curr Anthropol. 1995;36:159-97.

McBrearty S, Brooks L. The revolution that wasn't: a new interpretation of the origin of modern human behaviour. J Hum Evol. 2000;38:453-563.

Mellars P. The Neanderthal legacy: an archaeological perspective from Western Europe. Princeton: Princeton University Press; 1996.

Mellars P. The Neanderthal problem continued. Curr Anthropol. 1999;40:341-64.

Mellars P. The impossible coincidence. A single-species model for the origins of modern human behavior in Europe. Evol Anthropol. 2005;14:12-27.

Nicholson E, Harvati K. Quantitative analysis of human mandibular shape using 3-D geometric morphometrics. Am J Phys Anthropol. 2006;131:368-83.

Ogilvie MD, Curran BK, Trinkaus E. Prevalence and pattern of dental enamel hypoplasia among the Neandertals. Am J Phys Anthropol. 1989;79:25-41.

Orlando L, Darlu P, Toussaint M, Bonjean D, Otte M, Hänni C. Revisiting Neandertal diversity with a 100,000 year old mtDNA sequence. Curr Biol. 2006;16:400-2.

Ovchinnikov IV, Götherström A, Romanova GP, Kharitonov VM, Lindén K, Goodwin W. Molecular analysis of Neandertal DNA from the Northern Caucasus. Nature. 2000;404:490-3.

Pearson OM. Postcranial remains and the origin of modern humans. Evol Anthropol. 2000;9:229-47.

Rak Y. The Neanderthal: a new look at an old face. J Hum Evol. 1986;15:151-64.

Rak Y. Does any Mousterian cave present evidence of the two hominid species? In: Akazawa T, Aoki K, Bar-Yosef O, editors. Neandertals and modern humans in western Asia. New York: Plenum; 1998. p. 353-66.
Ramírez Rozzi FV, Bermúdez de Castro JM. Surprisingly growth in Neanderthals. Nature. 2004;428:936-9.

Richards MP, Pettitt PB, Trinkaus E, Smith FH, Paunovic M, Karavanic I. Neanderthal diet at Vindija and Neanderthal predation: the evidence from stable isotopes. Proc Natl Acad Sci USA. 2000;97:663-7666.

Richards MP, Pettitt PB, Stiner MC, Trinkaus E. Stable isotope evidence for increasing dietary breadth in the European midUpper Paleolithic. Proc Natl Acad Sci USA. 2001;98:6528-32.

Richards MP, Jacobi R, Cook J, Pettitt PB, Stringer CB. Isotope evidence for the intensive use of marine foods by Late Upper Palaeolithic humans. J Hum Evol. 2005;49:390-4.

Rosas A, Bastir M, Martinez-Maza C, Garcia-Tabernero A, LaluezaFox C. Inquiries into Neanderthal craniofacial development and evolution: "accretion" versus "organismic" models. In: Harvati K, Harrison T, editors. Neanderthals revisited: new approaches and perspectives. Dordrecht: Springer; 2006. p. 37-70.

Ruff CB. Climate, body size and body shape in hominid evolution. J Hum Evol. 1991;21:81-105.

Ruff CB, Trinkaus E, Hollliday TW. Body mass and encephalization in Pleistocene Homo. Nature. 1997;387:173-6.

Sawyer GJ, Maley B. Neanderthal reconstructed. Anat Rec B New Anat. 2005;283B:23-31.

Serre D, Langaney A, Chech M, Teschler-Nicola M, Paunovic M, Mennecier P, et al. No evidence of Neandertal mtDNA contribution to early modern humans. PLoS Biol. 2004;2:313-7.

Schmitz RW, Serre D, Bonani G, Feine S, Hillgruber F, Krainitzki H, et al. The Neandertal type site revisited: interdisciplinary investigations of skeletal remains from the Neander Valley, Germany. Proc Natl Acad Sci USA. 2002;99:13342-7.

Schwartz JH, Tattersall I. Toward distinguishing Homo neanderthalensis from Homo sapiens, and vice versa. L'Anthropologie. 1996;34:7988.

Shea JS, Brooks AS. Mousterian. In: Delson E, Tattersall I, Van Couvering JA, Brooks AS, editors. Encyclopedia of human evolution and prehistory. 2nd ed. New York: Garland; 2000. p. 453-60.

Skinner M. Dental wear in immature Late Pleistocene hominines. J Archaeol Sci. 1997;24:677-700.

Smith FH. Upper Pleistocene hominid evolution in South-Central Europe: a review of the evidence and analysis of Trends. Curr Anthropol. 1982;23:667-703.

Smith FH. The Neandertals: evolutionary dead ends or ancestors of modern people? J Anthropol Res. 1991;47:219-38.

Smith TM, Toussaint M, Reid DJ, Olejniczak AJ, Hublin JJ. Rapid dental development in a Middle Paleolithic Belgian Neanderthal. Proc Natl Acad Sci USA. 2007;104:20220-5.

Soficaru A, Petrea C, Dobos A, Trinkaus E. The human cranium from the Pes, tera Cioclovina Uscata? Romania. Curr Anthropol. 2007;48:611-9.

Spoor F, Hublin JJ, Braun M, Zonneveld F. The bony labyrinth of Neanderthals. J Hum Evol. 2003;44:141-65.

Stewart JR, van Kolfschoten T, Markova A, Musil R. Neanderthals as part of the broader Late Pleistocene megafaunal extinctions? In: van Andel T, Davies W, editors. Neanderthals and modern humans in the European landscape during the last glaciation. Cambridge: McDonald Institute for Archaeological Research; 2003. p. 221-31.

Stewart JR. The ecology and adaptation of Neanderthals during the non-analogue environment of oxygen isotope stage 3. Quat Int. 2005; 137:35-46.

Stiner MC. Honor among thieves: a zooarchaeological study of Neandertal ecology. Princeton: Princeton University Press; 1994.

Stringer CB. Population relationships of Later Pleistocene hominids: a multivariate study of available crania. J Archaeol Sci. $1974 ; 1: 317-142$. 
Stringer CB, Andrews P. Genetic and fossil evidence for the origin of modern humans. Science. 1988;239:1263-8.

Stringer CB, Hublin JJ, Vandermeersch B. The origin of anatomically modern humans in Western Europe. In: Smith FH, Spencer F, editors. The origins of modern humans: a world survey of the fossil evidence. New York: Liss; 1984. p. 51-135.

Stringer C, Palike H, van Andel TH, Huntley B, Valdes P, Allen JRM. Climatic stress and the extinction of Neanderthals. In: van Andel T, Davies W, editors. Neanderthals and modern humans in the European landscape during the last glaciation. Cambridge: McDonald Institute for Archaeological Research; 2003. p. 23340.

Stringer CB, Finlayson JC, Barton RNE, Fernández-Jalvo Y, Cáceres IRC, Sabin RC, et al. Neanderthal exploitation of marine mammals in Gibraltar. Proc Natl Acad Sci USA. 2008;105:14319 24.

Tattersall I. Species concepts and species identification in human evolution. J Hum Evol. 1992;22:341-9.

Tattersall I. Paleoanthropology: the last half-century. Evol Anthropol. 2000;9:2-16.

Tattersall I, Schwartz JH. Hominids and hybrids: the place of Neandertals in human evolution. Proc Natl Acad Sci USA. 1999;96:7117-9.

Tattersall I, Schwartz JH. The distinctiveness and systematic context of Homo neanderthalensis. In: Harvati K, Harrison T, editors. Neanderthals revisited: new approaches and perspectives. Dordrecht: Springer; 2006. p. 9-22.

Thieme H. Lower Paleolithic hunting weapons from Schöningen, Germany - the oldest spears in the world. Acta Anthropol Sin. 2000;S19:140-7.

Trinkaus E. The Shanidar Neanderthals. New York: Academic; 1983.
Trinkaus E. The Neandertal face: evolutionary and functional perspectives on a recent hominid face. J Hum Evol. 1987;16:429 43.

Trinkaus E. Neanderthal mortality patterns. J Archaeol Sci. 1995;22:121-42.

Trinkaus E, Shipman P. Neanderthals: images of ourselves. Evol Anthropol. 1993;1:194-201.

Trinkaus E, Moldovan O, Milota S, Bilgar A, Sarcina L, Athreya S, et al. An early modern human from the Peștera cu Oase, Romania. Proc Natl Acad Sci USA. 2003;100:11231-6.

Tzedakis C, Hughen K, Cacho I, Harvati K. Placing late Neanderthals in a climatic context. Nature. 2007;449:206-8.

van Andel T, Davies W. Neanderthals and modern humans in the European landscape during the last glaciation. Cambridge: McDonald Institute Monographs; 2003.

Weaver TD. The shape of the Neandertal femur is primarily the consequence of a hyperpolar body form. Proc Natl Acad Sci USA. 2003;100:6926-9.

Weaver TD, Roseman C. Ancient DNA, late Neandertal survival, and Modern-human-Neandertal genetic admixture. Curr Anthropol. 2005;46:677-83.

Weaver TD, Roseman CC, Stringer CB. Were Neandertal and modern human cranial differences produced by natural selection or genetic drift? J Hum Evol. 2007;53:135-45.

Zilhão J, d'Errico F. The chronology and taphonomy of the earliest Aurignacian and its implications for the understanding of Neanderthal extinction. J World Prehist. 1999;13:1-68.

Zubrow E. The demographic modeling of Neanderthal extinction. In: Mellars P, Stringer C, editors. The human revolution. Princeton: Princeton University Press; 1989. p. 212-31. 